Article

\title{
Angiotensin II Type 1 Receptor Antagonist Losartan Inhibits TNF- $\alpha$-Induced Inflammation and Degeneration Processes in Human Nucleus Pulposus Cells
}

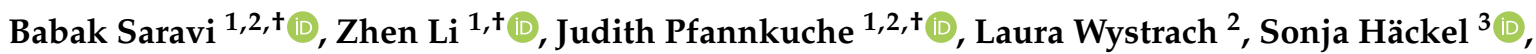 \\ Christoph E. Albers ${ }^{3}$, Sibylle Grad ${ }^{1}{ }^{\circledR}$, Mauro Alini ${ }^{1}{ }^{1}$, Robert Geoffrey Richards $\left.{ }^{1}{ }^{(}\right)$, Corinna Lang ${ }^{4,5}$, \\ Norbert Südkamp ${ }^{2}$, Hagen Schmal ${ }^{2}$ (I) and Gernot Lang ${ }^{2, *}$ (i)
}

check for

updates

Citation: Saravi, B.; Li, Z.;

Pfannkuche, J.; Wystrach, L.; Häckel,

S.; E. Albers, C.; Grad, S.; Alini, M.;

Richards, R.G.; Lang, C.; et al.

Angiotensin II Type 1 Receptor

Antagonist Losartan Inhibits

TNF- $\alpha$-Induced Inflammation and Degeneration Processes in Human Nucleus Pulposus Cells. Appl. Sci. 2021, 11, 417. https://doi.org/ 10.3390/app11010417

Received: 16 November 2020 Accepted: 30 December 2020 Published: 4 January 2021

Publisher's Note: MDPI stays neutral with regard to jurisdictional clai$\mathrm{ms}$ in published maps and institutional affiliations.

Copyright: (C) 2021 by the authors. Licensee MDPI, Basel, Switzerland. This article is an open access article distributed under the terms and conditions of the Creative Commons Attribution (CC BY) license (https:// creativecommons.org/licenses/by/ $4.0 /)$.
1 AO Research Institute Davos, Clavadelerstrasse 8, 7270 Davos, Switzerland; babak.saravi@jupiter.uni-freiburg.de (B.S.); zhen.li@aofoundation.org (Z.L.); jjpfannkuche@gmail.com (J.P.); sibylle.grad@aofoundation.org (S.G.); mauro.alini@aofoundation.org (M.A.); geoff.richards@aofoundation.org (R.G.R.)

2 Department of Orthopedics and Trauma Surgery, Medical Centre-Albert-Ludwigs-University of Freiburg, Faculty of Medicine, Albert-Ludwigs-University of Freiburg, Hugstetterstrasse 55, 79106 Freiburg, Germany; laura.wystrach@uniklinik-freiburg.de (L.W.); norbert.suedkamp@uniklinik-freiburg.de (N.S.); hagen.schmal@uniklinik-freiburg.de (H.S.)

3 Department of Orthopaedic Surgery and Traumatology, Inselspital, Bern University Hospital, University of Bern, Freiburgstrasse 18, 3010 Bern, Switzerland; Sonja.haeckel@insel.ch (S.H.); Christoph.Albers@insel.ch (C.E.A.)

4 Department of Cardiology and Angiology I, Faculty of Medicine, Heart Center Freiburg University, University of Freiburg, Hugstetter Str. 55, 79106 Freiburg, Germany; Corinna.Nadine.Lang@uniklinik-freiburg.de

5 Department of Medicine III (Interdisciplinary Medical Intensive Care), Medical Center, Faculty of Medicine, University of Freiburg, Hugstetter Str. 55, 79106 Freiburg, Germany

* Correspondence: gernot.michael.lang@uniklinik-freiburg.de

+ These authors contributed equally to this manuscript.

Abstract: Our recent study detected the expression of a tissue renin-angiotensin system (tRAS) in human intervertebral discs (IVDs). The present study sought to investigate the impact of the angiotensin II receptor type 1 (AGTR1) antagonist losartan on human nucleus pulposus (NP) cell inflammation and degeneration induced by tumor necrosis factor- $\alpha$ (TNF- $\alpha$ ). Human NP cells (4 donors; Pfirrmann grade 2-3; 30-37-years-old; male) were isolated and expanded. TNF- $\alpha(10 \mathrm{ng} / \mathrm{mL})$ was used to induce inflammation and degeneration. We examined the impact of losartan supplementation and measured gene expression of tRAS, anabolic, catabolic, and inflammatory markers in NP cells after 24 and $72 \mathrm{~h}$ of exposure. T0070907, a PPAR gamma antagonist, was applied to examine the regulatory pathway of losartan. Losartan $(1 \mathrm{mM})$ significantly impaired the TNF- $\alpha$-induced increase of pro-inflammatory (nitric oxide and TNF- $\alpha$ ), catabolic (matrix metalloproteinases), and tRAS (AGTR1a and angiotensin-converting enzyme) markers. Further, losartan maintained the NP cell phenotype by upregulating aggrecan and downregulating collagen type I expression. In summary, losartan showed anti-inflammatory, anti-catabolic, and positive phenotype-modulating effects on human NP cells. These results indicate that tRAS signaling plays an important role in IVD degeneration, and tRAS modulation with losartan could represent a novel therapeutic approach.

Keywords: intervertebral disc; renin-angiotensin system; degeneration; regeneration; spine; inflammation

\section{Introduction}

Low back pain (LBP) is one of the most common health problems and a leading cause of disability worldwide, resulting in an enormous socioeconomic burden [1]. Symptomatic intervertebral disc degeneration (IDD) is a major cause of LBP [2]. IDD is associated with extracellular matrix (ECM) degradation, the release of pro-inflammatory cytokines, alterations in spine biomechanics, increased angiogenesis, and neo-innervation, resulting in 
discogenic pain and disability [3,4]. Pro-inflammatory cytokines affect the production of relevant catabolic enzymes, leading to progressive ECM degeneration. Several studies have shown that pro-inflammatory markers, such as tumor necrosis factor-alpha (TNF- $\alpha$ ) and interleukin (IL)-6, are increasingly expressed in degenerated human IVDs [4,5].

At present, none of the available treatment strategies address the actual underlying pathologic dysregulations leading to IDD. Affected patients in the early stages of IVD degeneration and not qualified for surgery do not benefit from conservative treatments [6]. Surgical strategies that include spinal fusion or total disc replacement (TDR) have been introduced and carried out to treat symptomatic patients, even though the long-term benefit is elusive compared with conservative treatment options [7-10]. Given the dearth of adequate self-repair capabilities of IVDs and satisfactory treatment approaches, new biomolecular therapies targeting the inflammatory and degenerative cycles are receiving attention [11]. These approaches attempt to reduce the inflammatory settings of degenerative and inflammatory IVDs in order to slow down the progressive pro-inflammatory cascade [12-15].

Recently, we showed that the tissue renin-angiotensin system (tRAS) is expressed in human IVDs, revealing a positive correlation with pro-inflammatory cytokines and catabolic enzymes [16]. Angiotensin II (AngII) is the major effector of the tRAS and is involved in inflammatory cell pathways. Angiotensinogen (ATG), its precursor protein, is cleaved by the protease renin to produce AngI, which is then converted to biologically active AngII by angiotensin-converting enzyme (ACE). RAS inhibitors are one of the most prescribed drugs globally [17]. Recent research has raised evidence that RAS inhibitors could reduce TNF- $\alpha$ production both in vitro and in vivo $[18,19]$. Price et al. showed in a rat model of rheumatoid arthritis (RA) that TNF- $\alpha$ production and pathological characteristics, such as knee joint swelling, were significantly diminished by ACE inhibitor application [20]. These findings were also confirmed by other groups, revealing that ACE inhibitors and angiotensin II receptor type 1 blockers (ARBs) are associated with anti-arthritic effects through the reduction of reactive oxygen species, inflammation, neutrophil recruitment, disease activity, and finally joint destruction [21-34]. Moreover, animal models of renal injury examining the protective impact of RAS inhibitors revealed that inhibition of AngII functions via ACE inhibitors or ARBs reduced the recruitment of pro-inflammatory cells and catabolic gene expression [35-37].

We hypothesize that a local RAS is involved in the progress of disc degeneration, inflammation, and discogenic pain in human IVD cells. As inflammation contributes to IDD, the present study sought to investigate whether inhibition of the angiotensin II receptor type 1 (AGTR1) would have a protective effect on IVD tissue biology. Specifically, we investigated the potential protective effects of angiotensin II receptor type 1 antagonist losartan on human nucleus pulposus (NP) cell inflammation and degeneration induced by TNF- $\alpha$.

\section{Materials and Methods}

\subsection{Isolation and Expansion of Human NP Cells}

The Swiss Human Research Act does not apply to research that utilizes anonymized biological material and/or anonymously collected or anonymized health-related data. Therefore, this project does not need to be approved by an ethics committee. Patients' general consent, which also covers anonymization of health-related data and biological material, was obtained. Human NP waste tissue was collected from patients that underwent spinal surgeries with written consent (4 donors, male, 31-37 years old, Pfirrmann grade II). The collected NP tissue was incubated with red blood cell lysis buffer $\left(155 \mathrm{mM} \mathrm{NH}_{4} \mathrm{Cl}\right.$, $10 \mathrm{M} \mathrm{KHCO}_{3}$, and $0.1 \mathrm{mM}$ EDTA in Milli-Q water) for $5 \mathrm{~min}$ on a shaker at room temperature, and then washed with Phosphate-Buffered Saline (PBS). Chopped tissue was then enzymatically digested with $0.2 \% w / v$ pronase (Roche, Basel, Switzerland) in Alpha Minimum Essential Medium ( $\alpha$ MEM, Gibco) for $1 \mathrm{~h}$, followed by $65 \mathrm{U} / \mathrm{mL}$ collagenase type II (Worthington, Columbus, OH, USA) in $\alpha \mathrm{MEM} / 10 \%$ Fetal Calf Serum (FCS, Corning, 
Corning, NY, USA) at $37^{\circ} \mathrm{C}$ for $12-14 \mathrm{~h}$. A single-cell suspension was obtained by filtering through a $100 \mu \mathrm{m}$ cell strainer. Next, cells were seeded at a density of 10,000 cells $/ \mathrm{cm}^{2}$ and expanded with $\alpha$ MEM supplemented with $10 \%$ FCS, $100 \mathrm{U} / \mathrm{mL}$ penicillin, and $100 \mathrm{mg} / \mathrm{mL}$ streptomycin ( $1 \% \mathrm{P} / \mathrm{S}$, Gibco). Cells were cultured at a hypoxic condition of $2 \% \mathrm{O}_{2}$. The culture medium was changed twice a week and cells were detached at approximately $80 \%$ confluence using a dissociation buffer composed of $0.05 \%$ trypsin/EDTA (Gibco) for 5 min at $37^{\circ} \mathrm{C}$. Cells were sub-cultured at a cell density of 3000 cells $/ \mathrm{cm}^{2}$ for expansion. Passage 1 NP cells were cryopreserved in liquid $\mathrm{N}_{2}$. After thawing, NP cells were expanded with high-glucose Dulbecco's Minimum Essential Medium (high glucose DMEM, Sigma-Aldrich, St. Louis, MO, USA) and 10\% FCS. Passage 3 NP cells were used in the present study.

\subsection{Cytotoxicity Test of Losartan}

Cytotoxicity studies were performed to test whether losartan induced cell death of human NP cells at different doses and time points. Human NP cells were seeded in 96-well plates at a density of 2000 cells per well for cell viability analysis. Two donors with three technical replicates per donor were used for analysis. The groups were exposed to DMEM with $1 \%$ ITS+, $1 \%$ non-essential amino acids (Sigma-Aldrich, St. Louis, MO, USA), and $50 \mu \mathrm{g} / \mathrm{mL}$ L-ascorbic acid 2-phosphate (Sigma-Aldrich, St. Louis, MO, USA). After $24 \mathrm{~h}$, losartan (Tocris Bioscience, Bristol, UK) was added to the treatment groups at concentrations of 100, 250, 500, 750, and $1000 \mu \mathrm{M}$. After incubation for 24, 48, and $72 \mathrm{~h}$, the cells were washed with PBS and then exposed to the Cell Titer Blue ${ }^{\circledR}$ reagent (Promega Corporation, Madison, WI, USA) diluted 1:5 in DMEM. Fluorescence intensity was determined with the Viktor 3 plate reader (Perkin Elmer, Waltham, MA, USA) after $4 \mathrm{~h}$ of incubation (ex/em 560/590 nm).

\subsection{Effect of Losartan on Human NP Cells}

Passage 3 NP cells were seeded in 12-well plates at a density of 20,000 cells/well. Overall, four donors with three replicates per donor were assessed in this experiment. Additionally, three wells per group and donor were assessed for DNA content. Cells were seeded in 2 mL DMEM with 10\% FCS to allow cell attachment. On the day of seeding the 12-well plates (Day 0, baseline), samples were taken for normalization. After $24 \mathrm{~h}$, the medium was changed to the experiment medium with six groups. The control group was cultured with $2 \mathrm{~mL}$ DMEM, 1\% non-essential amino acids, $50 \mu \mathrm{g} / \mathrm{mL}$ L-ascorbic acid 2-phosphate, and 1\% ITS+. We prepared high-dose $(1000 \mu \mathrm{M})$ and low-dose $(100 \mu \mathrm{M})$ stock solutions of losartan by dissolving $47.9 \mathrm{mg}$ losartan potassium and $4.79 \mathrm{mg}$, respectively, in $1 \mathrm{~mL}$ PBS. After sterile filtering with a $0.2 \mu \mathrm{m}$ filter, we prepared $250 \mu \mathrm{L}$ aliquots and stored them at $-20{ }^{\circ} \mathrm{C}$. Losartan at concentrations of $100-1000 \mu \mathrm{M}$ in PBS was then added to the medium for the experiments. Human recombinant TNF- $\alpha(10 \mathrm{ng} / \mathrm{mL})$ was added simultaneously to induce a pro-inflammatory stimulus in human NP cells.

Experimental groups:

- Control group

- $\quad$ Losartan $100 \mu \mathrm{M}$

- $\quad$ Losartan $1000 \mu \mathrm{M}$

- $\quad$ TNF- $\alpha 10 \mathrm{ng} / \mathrm{mL}$

- $\quad$ TNF- $\alpha 10 \mathrm{ng} / \mathrm{mL}+$ Losartan $100 \mu \mathrm{M}$

- $\quad$ TNF- $\alpha 10 \mathrm{ng} / \mathrm{mL}+$ Losartan $1000 \mu \mathrm{M}$

After treatment for $72 \mathrm{~h}$, the medium was collected and analyzed for nitric oxide (NO) content. Three wells / group were digested with $0.5 \mathrm{mg} / \mathrm{mL}$ proteinase $\mathrm{K}$ (Sigma-Aldrich, St. Louis, MO, USA) to measure DNA content in the monolayer. Three wells/group were lysed in TRI reagent (Molecular Research Center, Cincinnati, OH, USA) and PolyAcrylCarrier (Molecular Research Center, Cincinnati, $\mathrm{OH}, \mathrm{USA}$ ), and stored at $-80{ }^{\circ} \mathrm{C}$ for gene expression analysis. 


\subsection{Pathway Study with the Peroxisome Proliferator-Activated Receptor Gamma (PPAR $\gamma$ )} Antagonist T0070907 under Inflammatory Conditions

To determine a potential pathway for the anti-inflammatory effect of losartan, we conducted a pathway study with the PPAR $\gamma$ antagonist T0070907 (Tocris Bioscience, Bristol, $\mathrm{UK})$. Human recombinant TNF- $\alpha(10 \mathrm{ng} / \mathrm{mL})$ was used as an inducer of inflammation. T0070907 was added to the medium to investigate whether losartan's anti-inflammatory effect would be inhibited by blocking PPAR $\gamma$. DMSO was used to solubilize T0070907 and the same amount ( $1 \mu \mathrm{L} / \mathrm{mL}$ medium) was also added to the other groups to provide equivalent culture conditions. As before, the cells were seeded on day 0 and exposed to the experimental group medium after $24 \mathrm{~h}$. Gene expression analysis was performed after 24 and $48 \mathrm{~h}$ of exposure. The experimental groups were:

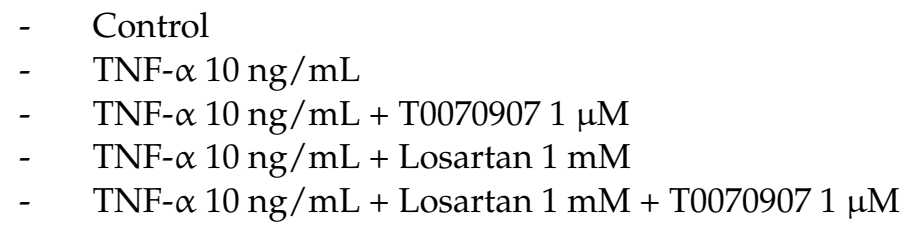

\subsection{Gene Expression Analysis}

Total RNA was extracted with 1-bromo-3-chloropropane (Sigma-Aldrich) followed by RNA precipitation using isopropanol and high salt precipitation solution $(0.8 \mathrm{M}$ sodium citrate and 1.2 M NaCl). RNA was washed with ethanol and quantified using a NanoDrop ND-1000 spectrophotometer (Thermo Fisher Scientific Inc., Waltham, MA, USA). SuperScript VILO cDNA Synthesis Kit (Life Technologies, Carlsbad, CA, USA) was used for reverse transcription, followed by real-time quantitative PCR (qRT-PCR) using the TaqMan $^{\mathrm{TM}}$ method with $10 \mu \mathrm{L}$ reaction volume.

qRT-PCR was performed to assess the gene expression of matrix metalloproteinase-1 and -3 (MMP-1, -3), interleukin 6 and 8 (IL-6, -8), TNF- $\alpha$, and PPAR $\gamma$ as markers for inflammation and matrix degradation. Aggrecan (ACAN), collagen I, and collagen II (COL I, II) were analyzed as markers for ECM production and cell phenotype identification. The mRNA expression levels of the following components of tRAS were also quantified: angiotensin-converting enzyme (ACE), angiotensinogen (AGT), renin-like tRAS equivalent Cathepsin D, and the angiotensin II receptor type I (AGTR1). RPLP0 was used as a housekeeping gene in each sample (Table 1). The comparative CT method was applied for relative quantification with RPLP0 as the endogenous control.

\subsection{Biochemical Analysis}

DNA content was measured after overnight digestion with $0.5 \mathrm{mg} / \mathrm{mL}$ proteinase $\mathrm{K}$ (Sigma-Aldrich, St. Louis, MO, USA) at $56^{\circ} \mathrm{C}$. DNA quantification was performed with Hoechst 33258 (Sigma-Aldrich, St. Louis, MO, USA) dye and calf thymus DNA (SigmaAldrich, St. Louis, MO, USA) as the standard. Nitric oxide (NO), a marker for oxidative stress, was indirectly measured in the sampled medium of all wells by spectrophotometric quantification of nitrite, a non-volatile breakdown product, by Griess assay (Promega, Madison, WI, USA). 
Table 1. Characteristics of custom-designed primer-probes and gene expression assays (Applied Biosystems) used for gene expression analysis.

\begin{tabular}{|c|c|c|c|}
\hline Gene Acronym & Gene Full Name & Primer-Probe Sequence or Catalog Number & Reporter/Quencher \\
\hline$h R P L P 0$ & Human 605 acidic ribosomal protein $\mathrm{P} 0$ & 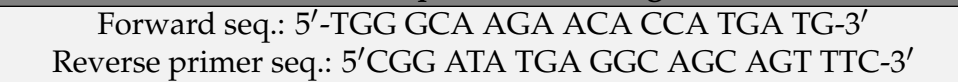 & FAM/TAMRA \\
\hline$h A C A N$ & Human Aggrecan & $\begin{array}{l}\text { Forward seq.: } 5^{\prime} \text {-AGT CTT CAA GCC TCC TGT ACT CA3' } \\
\text { Reverse primer seq.: } 5^{\prime} \text { CGG GAA GTG GCG GTA ACA-3 }{ }^{\prime}\end{array}$ & FAM/TAMRA \\
\hline$h A C E$ & $133(48.90)$ & Hs01586213_m1 & FAM/NFQ-MGB \\
\hline hAGTR1a & Human angiotensin-II receptor type 1 & Hs00258938_m1 & FAM/NFQ-MGB \\
\hline$h C T S D$ & Human Cathepsin D & Hs00157205_m1 & FAM/NFQ-MGB \\
\hline hCOL1A1 & Human collagen type 1 alpha 1 chain & $\begin{array}{c}\text { Forward seq.: } 5^{\prime}-\mathrm{CCC} \text { TGG AAA GAA TGG AGA TGA T-3' } \\
\text { Reverse primer seq.: } 5^{\prime} \text { ACT GAA ACC TCT GTG TCC CTT CA'3 }\end{array}$ & FAM/TAMRA \\
\hline$h C O L 2 A 1$ & Human collagen type 2 alpha 1 chain & $\begin{array}{c}\text { Forward seq.: } 5^{\prime}-\mathrm{GGC} \text { AAT AGC AGG TTC ACG TAC A-3' } \\
\text { Reverse primer seq.: } \text { 5'GAT AAC AGT CTT GCC CCA CTT ACC-3' }^{\prime} \text { AC }\end{array}$ & FAM/TAMRA \\
\hline hIL6 & Human Interleukin 6 & Hs00985639_m1 & FAM/NFQ-MGB \\
\hline hIL8 & Human Interleukin 8 & Hs00174103_m1 & FAM/NFQ-MGB \\
\hline hMMP1 & Human matrix-metalloproteinase 1 & Hs00899568_m1 & FAM/NFQ-MGB \\
\hline$h M M P 3$ & Human matrix-metalloproteinase 3 & Hs00968305_m1 & FAM/NFQ-MGB \\
\hline$h P P A R \gamma$ & Human peroxisome proliferator-activated receptor gamma & Hs00234592_m1 & FAM/NFQ-MGB \\
\hline hTNF $\alpha$ & Human tumor necrosis factor $\alpha$ & Hs00174128_m1 & FAM/NFQ-MGB \\
\hline
\end{tabular}




\subsection{Enzyme-Linked Immunosorbent Assay}

IL-6 content in the collected culture medium after $72 \mathrm{~h}$ of exposure was measured with an enzyme-linked immunosorbent (ELISA) kit (ELISA DuoSet ${ }^{\circledR}$, R\&D Systems, Catalog \# DY008). The capture antibody was diluted to the working concentration and the microplate was coated with $100 \mu \mathrm{L}$ per well with the diluted capture antibody, sealed, and incubated at room temperature overnight. On the next day, each well was aspirated and washed with a wash buffer (0.05\% Tween20 in PBS, pH 7.2-7.4). The plates were then blocked by adding $300 \mu \mathrm{L}$ of blocking buffer (1\% Bovine Albumin Serum (BSA) in PBS, pH 7.2-7.4, filtered sterile $(0.2 \mu \mathrm{m}))$ to each well. The plate was incubated at room temperature for a minimum of $1 \mathrm{~h}$. The wash step was repeated and samples or standards were diluted in Reagent Diluent (0.1\% Bovine Albumin Serum (BSA), 0.05\% Tween 20 in Tris-buffered Saline (20 mM Trizma Base, $150 \mathrm{mM} \mathrm{NaCl}, \mathrm{pH} 7.2-7.4$, filtered sterile $(0.2 \mu \mathrm{m}))$. Then, the plate was sealed and incubated for $2 \mathrm{~h}$ at room temperature. The wash step was repeated and $100 \mu \mathrm{L}$ of working dilution of Streptavidin-HRP was added to each well. The well was sealed and incubated at room temperature for $20 \mathrm{~min}$ and protected from light. The wash step was repeated and $100 \mu \mathrm{L}$ of substrate solution (1:1 mixture of $\mathrm{H}_{2} \mathrm{O}_{2}$ and Tetramethylbenzidine) was added to each well. The plate was incubated for $20 \mathrm{~min}$ at room temperature and protected from light. Finally, the stop solution $\left(2 \mathrm{~N} \mathrm{H}_{2} \mathrm{SO}_{4}\right)$ was added to each well and the optical density of each well was determined using a microplate reader at $450 \mathrm{~nm}$ with wavelength correction at $570 \mathrm{~nm}$.

\subsection{Statistical Analysis}

Statistical analysis was performed using GraphPad Prism 8.0 software (GraphPad Software, Inc., La Jolla, CA, USA) and Stata Statistical Software Release 15 (StataCorp. 2011, College Station, TX, USA). Data were assessed with the Shapiro-Wilk normality test. For normally distributed data, the differences were assessed using t-test or ANOVA, as appropriate. The Kruskal-Wallis test, followed by the Mann-Whitney U test for pairwise comparisons, was used for non-parametric testing. A two-sided $p$-value $<0.05$ was considered significant.

\section{Results}

\subsection{Losartan Does Not Show Cytotoxic Effects on Human NP Cells}

At concentrations between 100 and $1000 \mu \mathrm{M}$, losartan did not significantly affect the cell viability of human NP cells (Figure 1). We observed an increase in viable cell numbers from 24 to $72 \mathrm{~h}$ for the control group and all losartan groups examined. This increase in cell count was not different between different concentrations of losartan. These results indicate no cytotoxic effects of 100-1000 $\mu \mathrm{M}$ losartan on human NP cells after 24-72 h of exposure. We used losartan at a concentration of $100 \mu \mathrm{M}$ and $1000 \mu \mathrm{M}$ for subsequent experiments based on the cytotoxicity study results.

\subsection{Effect of Losartan on Human NP Cell Proliferation and NO Release}

The different experimental media did not significantly alter the DNA content of the human NP cells after exposure for $72 \mathrm{~h}$. As expected, we observed a significant increase in NO release from the cells of the experimental groups containing TNF- $\alpha(p<0.001)$. Losartan addition did not significantly affect NO release other than the TNF- $\alpha$ only group after $72 \mathrm{~h}$ of exposure (Figure 2). 


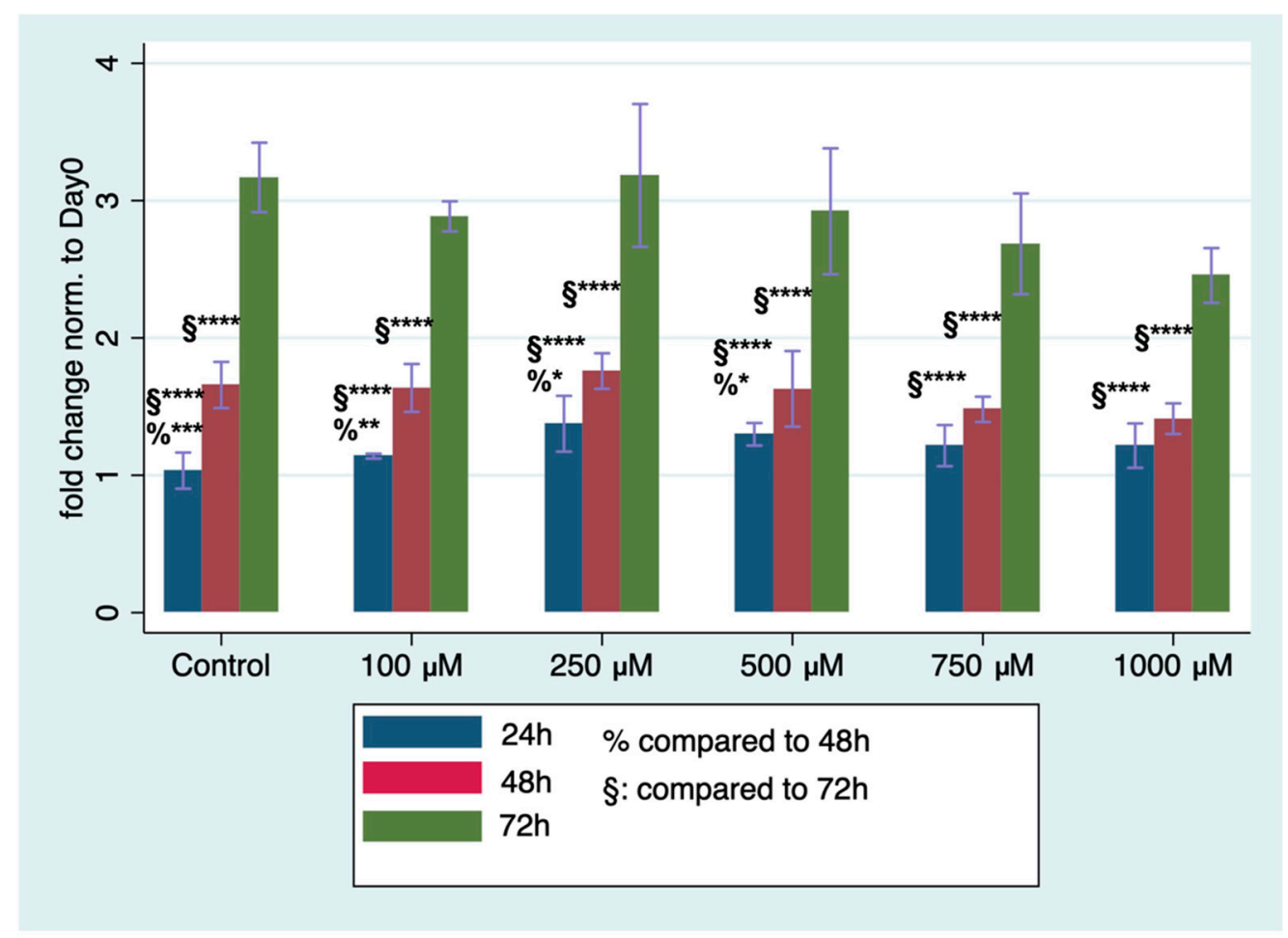

Figure 1. Relative viable cell count of human nucleus pulposus (NP) cells after 24,48 , and 72 h of losartan exposure. Means + standard deviations are shown. Data from two donors assessed in triplicate are shown $(n=6)$. \%: compared to $48 \mathrm{~h}$ of exposure; §: compared to $72 \mathrm{~h}$ of exposure; ${ }^{*} p<0.05 ;{ }^{* *} p<0.01 ;{ }^{* * *} p<0.001$; $^{* * * *} p<0.0001$.
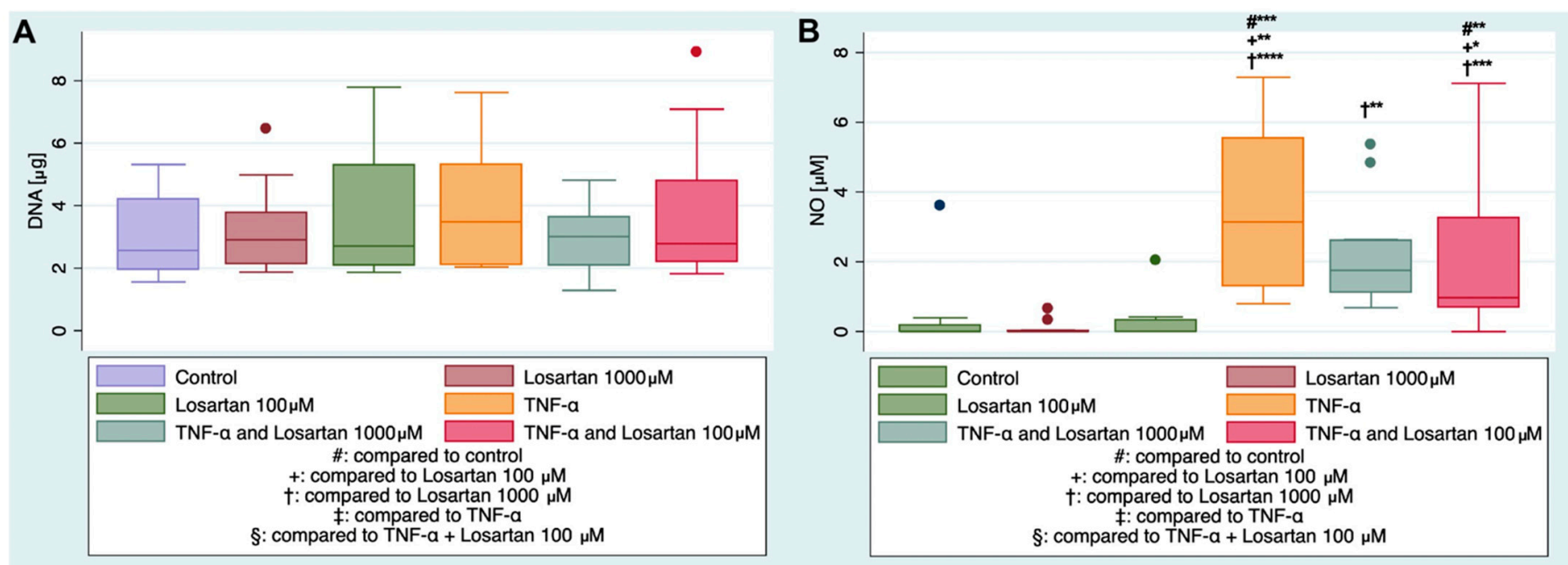

Figure 2. Effect of losartan and TNF- $\alpha$ on DNA content of human NP cells (A) and nitric oxide (NO) concentration in conditioned medium (B). Median and interquartile ranges (IQR) are shown. Dots represent outliers. Data from four donors assessed in triplicate are shown $(n=12)$. \#: compared to control; +: compared to Losartan $100 \mu \mathrm{M}$; + : compared to Losartan $1000 \mu \mathrm{M}$; ‡: compared to TNF- $\alpha$; §: compared to TNF- $\alpha+\operatorname{Losartan} 100 \mu \mathrm{M} ;{ }^{*} p<0.05 ;{ }^{* *} p<0.01 ;{ }^{* * *} p<0.001 ;{ }^{* * * *} p<0.0001$.

\subsection{Losartan Positively Modulates the Phenotype of Human NP Cells under Pro-Inflammatory Conditions}

A significant upregulation of the pro-inflammatory cytokines IL-6 and IL-8 was observed under inflammatory conditions, which was unaltered by supplementation with losartan (Figure 3A). Gene expression of TNF- $\alpha$ was upregulated following the addition of TNF- $\alpha(p<0.01)$, a trend that could be decreased by the addition of $1000 \mu \mathrm{M}$ losar$\tan (p<0.01)$. Further, we found that the combination of $1000 \mu \mathrm{M}$ losartan $(p<0.001)$ 
and $100 \mu \mathrm{M}$ losartan $(p<0.01)$ with TNF- $\alpha$ induced an increase in PPAR $\gamma$ gene expression compared with the control group, indicating that the angiotensin II receptor type 1 was involved in the regulation of PPAR $\gamma$ expression through AGTR1 in inflammatory settings. TNF- $\alpha$ significantly increased pro-inflammatory tRAS markers ACE $(p<0.05)$ and AGTR1 $(p<0.01)$. This effect was downregulated by blocking the AGTR1 receptor with $1000 \mu \mathrm{M}$ losartan, which also downregulated AGT expression (TNF- $\alpha+$ Losartan vs. Control, $p<0.01$ ), indicating that this upregulation of pro-inflammatory tRAS markers was mediated through the AGTR1 receptor under inflammatory situations (Figure 3B). TNF- $\alpha$ also upregulated the expression of Cathepsin D $(p<0.01)$, which was not altered by losartan addition. TNF- $\alpha$ induced upregulation of MMP-3 showed decreasing trends upon the addition of $1000 \mu \mathrm{M}$ losartan, indicating an antidegenerative effect of high-dose losartan. However, this finding failed to reach significance $(p=0.2676)$ for the comparison TNF- $\alpha$ vs. TNF- $\alpha+1000 \mu \mathrm{M}$ losartan. Interestingly, when TNF- $\alpha$ was present, the addition of losartan significantly upregulated the gene expression of ACAN (TNF- $\alpha+1000 \mu \mathrm{M}$ losartan vs. TNF- $\alpha p<0.05$ ) and downregulated collagen I expression (TNF- $\alpha+1000 \mu \mathrm{M}$ losartan vs. TNF- $\alpha, p<0.05$ ), indicating a positive phenotype-modifying effect of losartan under inflammatory conditions (Figure 3C). However, this observation was not significant for collagen II gene expression (TNF- $\alpha+1000 \mu \mathrm{M}$ losartan vs. TNF- $\alpha$, n.s.).

\subsection{Pathway Study in Human NP Cells Treated with the PPAR $\gamma$ Antagonist T0070907 under Inflammatory Conditions}

We found potential interactions between AGTR1 inhibition and PPAR $\gamma$ gene expression changes; hence, we evaluated whether losartan could directly interact with the PPAR $\gamma$ receptor. We examined the impact of an additional group containing the PPAR $\gamma$ antagonist T0070907 on respective genes after $24 \mathrm{~h}$ (Figure 4) and $72 \mathrm{~h}$ (Figure 5) of exposure. For the inflammatory markers IL-6 $(p<0.01)$ and TNF- $\alpha(p<0.05)$, a significant upregulation of gene expression could be observed in the inflammatory groups compared with the control group after $24 \mathrm{~h}$, confirming the findings of the previous experiments (Figure 3 ). In accordance with the previous experiments, this increase was not attenuated by losartan for IL-6. For TNF- $\alpha$, a marked decrease was observed, which barely missed statistical significance (TNF- $\alpha$ vs. TNF- $\alpha+$ Losartan, $p=0.0883$ ). The suppression of TNF- $\alpha$-induced inflammation by the PPAR $\gamma$ antagonist T0070907 was not significant. A noticeable trend could be observed in the gene expression analysis of the catabolic marker MMP1. Here, significant upregulation was observed between the control group and inflammatory groups (Control vs. TNF- $\alpha, p<0.0001$ ), which could be decreased by the addition of losartan (TNF- $\alpha$ vs. TNF- $\alpha+$ Losartan, $p<0.0001$ ). This effect was reversed with T0070907 in the medium (TNF- $\alpha+$ Losartan vs. TNF- $\alpha+$ Losartan + T0070907, $p<0.0001$ ), indicating a partial agonism and anti-degenerative effects of losartan via the PPAR $\gamma$ receptor in human NP cells. Addition of TNF- $\alpha$ also led to a significant increase of ACAN. However, we did not observe any differences for the other experimental groups. Further, losartan reduced collagen I gene expression in TNF- $\alpha$-treated NP cells (TNF- $\alpha$ vs. TNF- $\alpha+$ Losartan, $p<0.001)$. T0070907 intervention seemed to attenuate this effect of losartan, although the difference was not significant $(p=0.1990)$. For collagen II gene expression, we did not find any relevant significant changes.

Concerning the expression of the tRAS genes, we observed an upregulation of gene expression for AGTR1a, ACE, AGT, and Cathepsin D in inflammatory conditions (Control vs. TNF- $\alpha$ : ACE $p<0.0001$, AGT $p<0.0001$, AGTR1a $p<0.01$; Figure 4). Losartan significantly reduced the upregulation of tRAS genes, which was reversed by the PPAR $\gamma$ antagonist T0070907 for ACE (TNF- $\alpha+$ Losartan vs. TNF- $\alpha+$ Losartan + T0070907 $p<0.01)$, Cathepsin D (TNF- $\alpha+$ Losartan vs. TNF- $\alpha+$ Losartan + T0070907 $p<0.01)$, and AGT (TNF- $\alpha+$ Losartan vs. TNF- $\alpha+$ Losartan + T0070907 $p<0.001$; Figure 4 ). This trend seemed to be consistent for the angiotensin II receptor type 1, although not significant $(p=0.4913)$. 


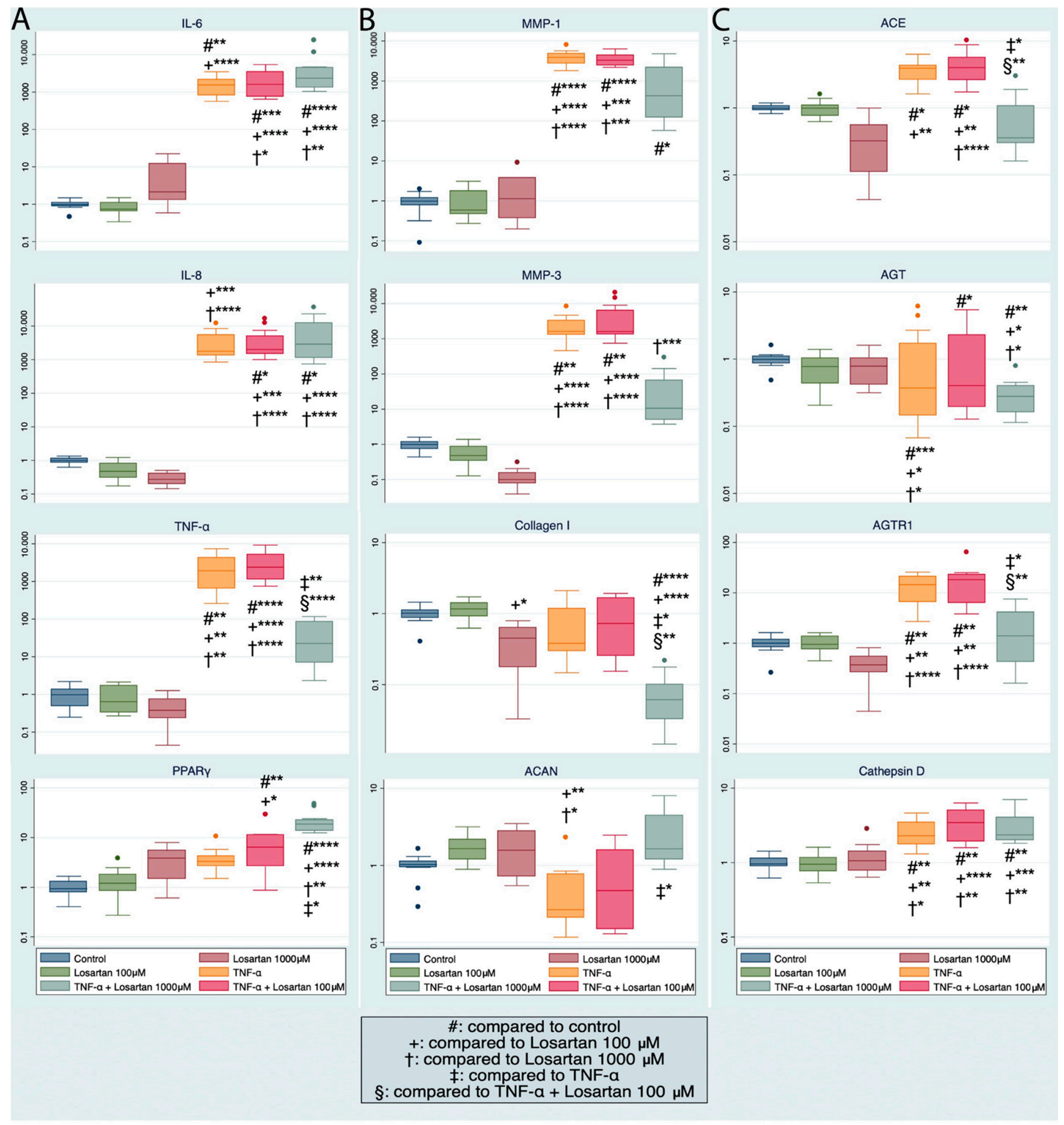

Figure 3. Gene expression of inflammatory (A), tissue remodeling (B), and tRAS markers (C) among the experimental groups. Gene expression was normalized to Day 0 (baseline) values. Data from four donors assessed in triplicate are shown $(n=12)$. \#: compared to control; +: compared to losartan $100 \mu \mathrm{M}$; †: compared to losartan $1000 \mu \mathrm{M}$; $:$ compared to TNF- $\alpha$; §: compared to TNF- $\alpha+\operatorname{losartan} 100 \mu \mathrm{M} ;{ }^{*} p<0.05 ;{ }^{* *} p<0.01 ;{ }^{* * *} p<0.001 ;{ }^{* * * *} p<0.0001$.

Figure 5 illustrates the gene expression results of the experimental groups after $72 \mathrm{~h}$ of exposure to the experimental groups' medium. There seemed to be a lower effect of all interventions on the examined genes with the increase of experimental duration. In contrast to the results after $24 \mathrm{~h}$ of exposure, we observed a downregulation of ACAN and collagen II for the TNF- $\alpha$ group, which was neutralized in the TNF- $\alpha+$ Losartan group 
only for ACAN. PPAR $\gamma$ antagonist T0070907 increased the gene expression for the tRAS genes Cathepsin D (TNF- $\alpha+$ Losartan vs. TNF- $\alpha+$ Losartan + T0070907, $p<0.01)$ and ACE (TNF- $\alpha+$ Losartan vs. TNF- $\alpha+$ Losartan + T0070907, $p<0.001)$, but not AGT and AGTR1 after $72 \mathrm{~h}$ of exposure. Further, T0070907 also reversed the anti-inflammatory effects of losartan with respect to TNF- $\alpha$ expression after $72 \mathrm{~h}$ of exposure $(p<0.05)$.
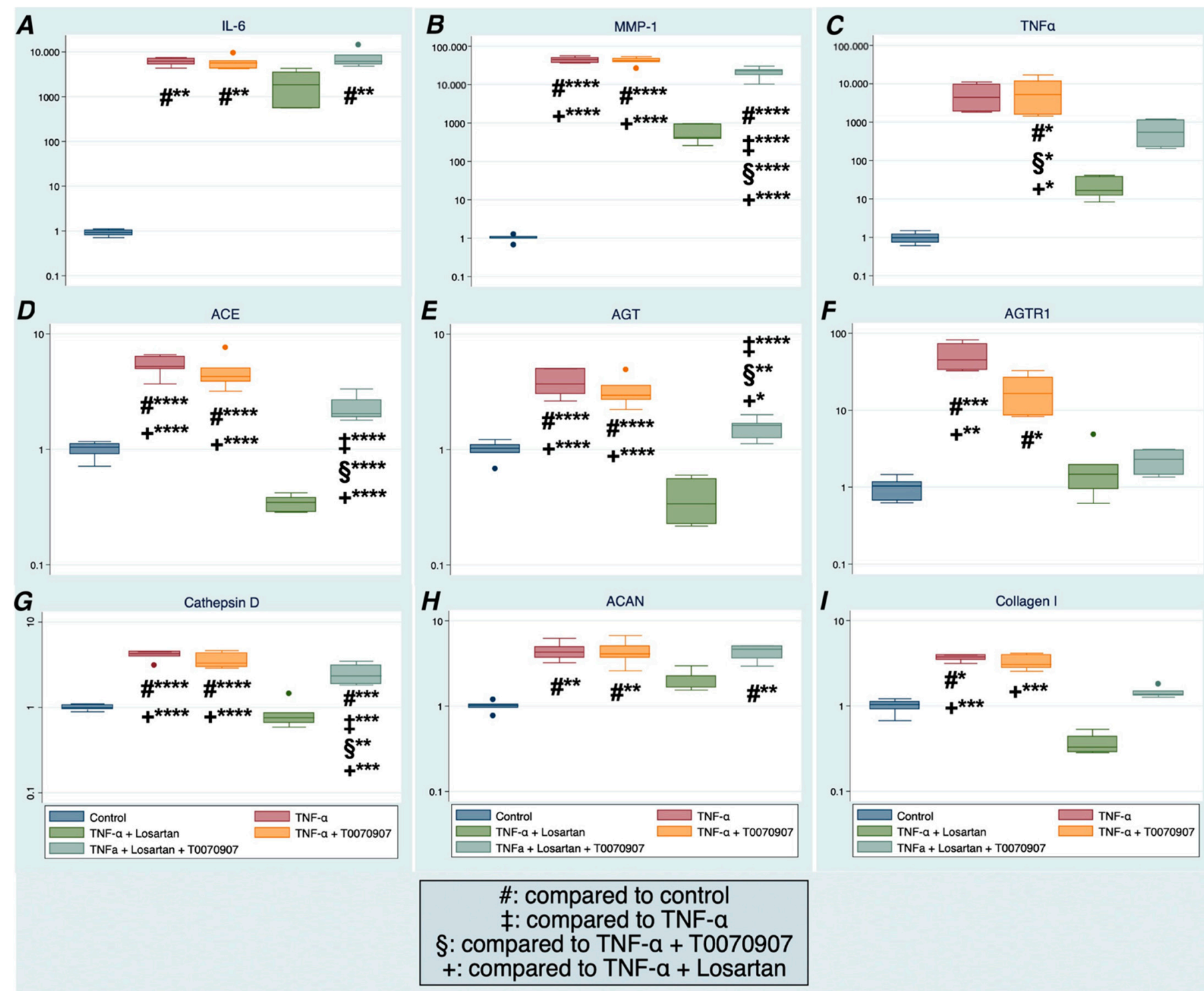

Figure 4. Influence of the PPAR $\gamma$ pathway on losartan-induced gene expression changes of inflammatory and tissue degeneration markers (A-C), tRAS markers (D-G), and cell phenotype markers (H,I) in human NP cells after 24 h of exposure. Gene expression was normalized to Day 0 (baseline) values. Data from two donors assessed in triplicate are shown $(n=6) ;{ }^{*} p<0.05 ;{ }^{* *} p<0.01 ;{ }^{* * *} p<0.001 ;{ }^{* * * *} p<0.0001$.

\subsection{Enzyme-Linked Immunosorbent Assay of Secreted IL-6}

The secreted IL- 6 levels in the culture medium were assessed by ELISA and are illustrated in Figure 6. TNF- $\alpha$ led to a significant and markedly upregulation of IL-6 levels. Losartan supplementation revealed a significant downregulation of IL-6 levels for the TNF- $\alpha+$ Losartan compared to the TNF- $\alpha$ only group $(p<0.001)$. However, PPAR $\gamma$ antagonist T0070907 was not able to significantly inhibit this downregulation. 

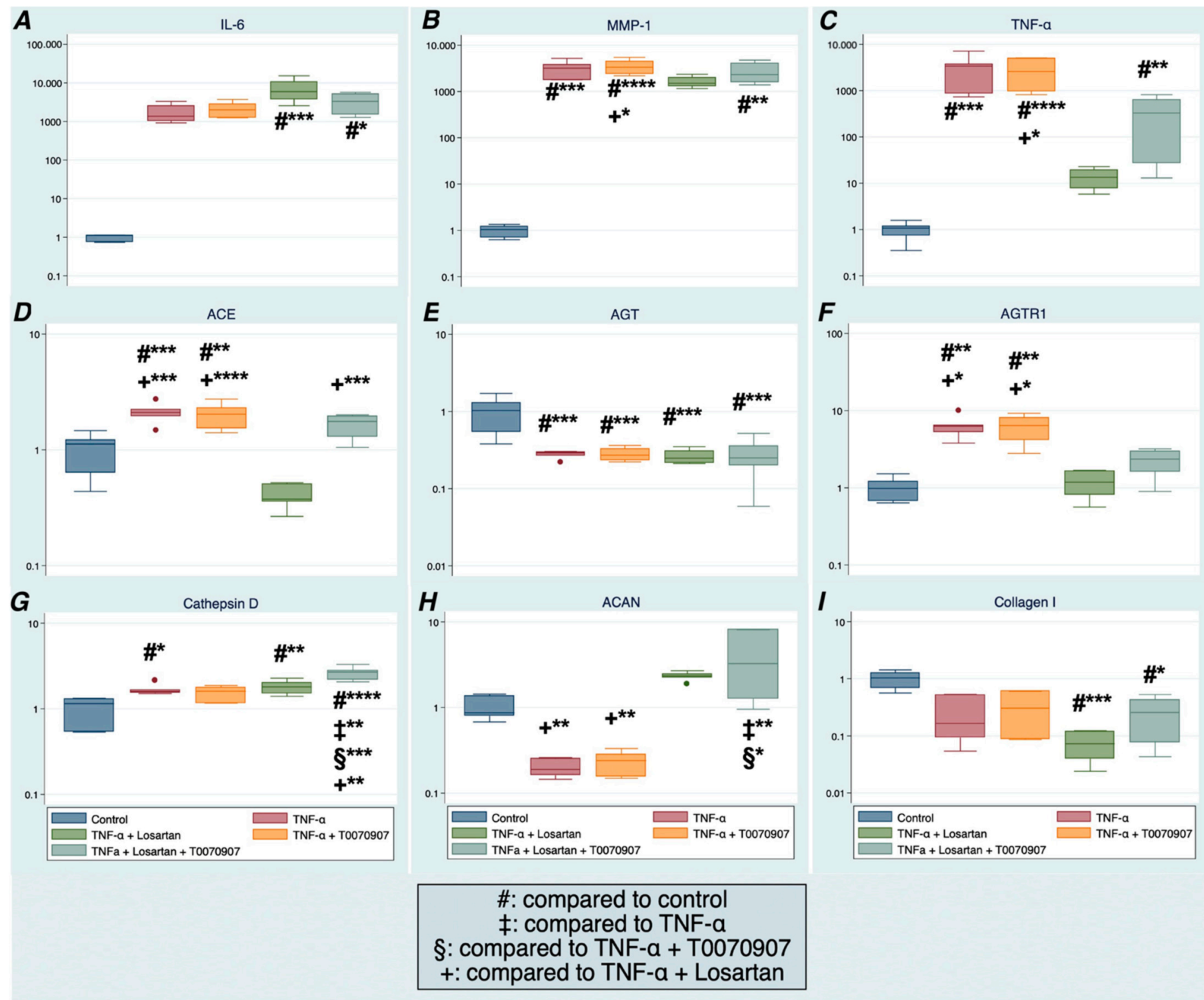

Figure 5. Influence of the PPAR $\gamma$ pathway on losartan-induced gene expression changes of inflammatory and tissue degeneration markers (A-C), tRAS markers (D-G), and cell phenotype markers $(\mathbf{H}, \mathbf{I})$ in human NP cells after $72 \mathrm{~h}$ of exposure. Gene expression was normalized to Day 0 (baseline) values. Data from two donors assessed in triplicate are shown $(n=6) ;^{*} p<0.05 ;{ }^{* *} p<0.01 ;{ }^{* * *} p<0.001 ;{ }^{* * * *} p<0.0001$. 


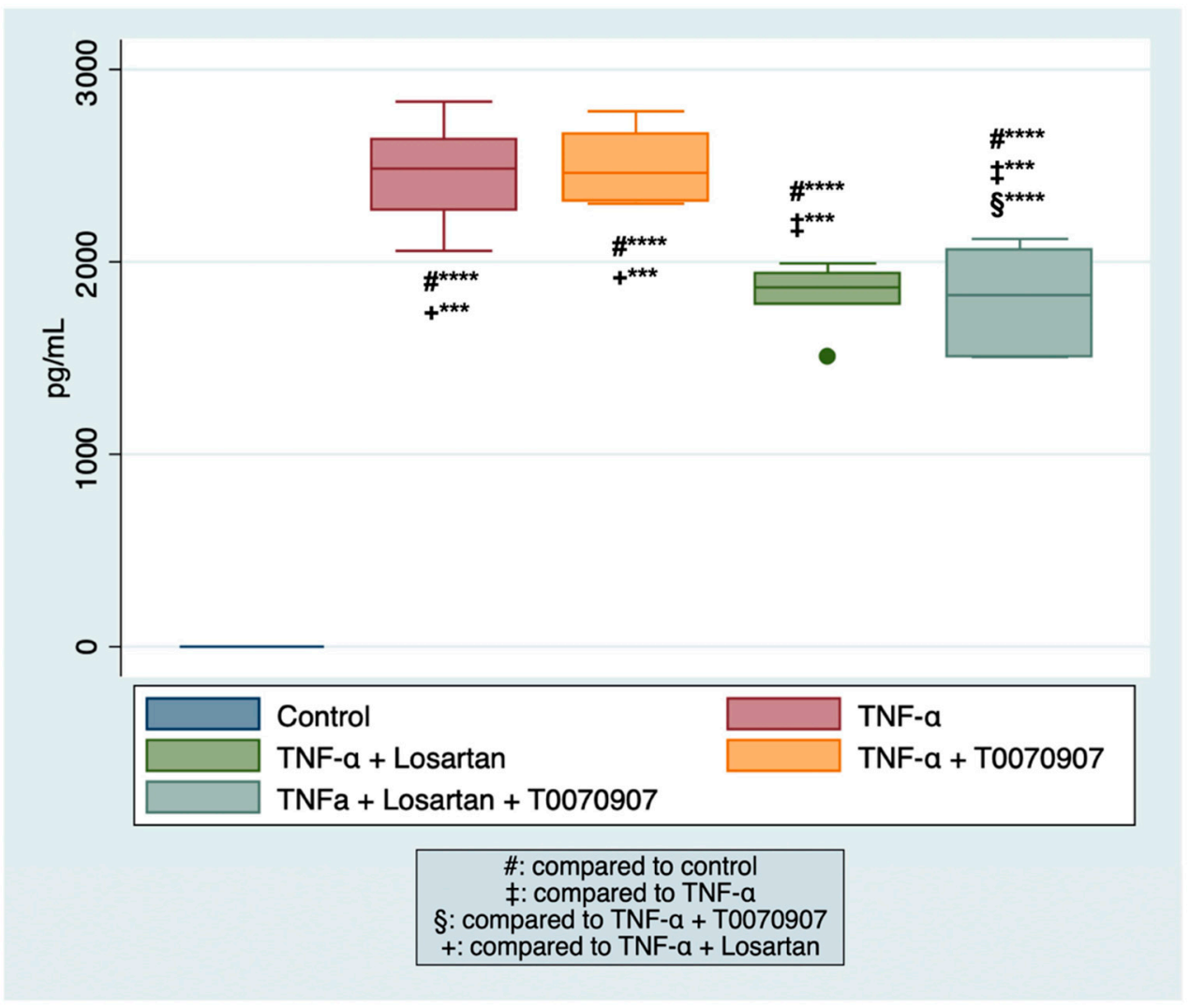

Figure 6. Influence of angiotensin II type 1 receptor (AGTR1) inhibition on secreted IL-6 levels in human NP cells after $72 \mathrm{~h}$ of exposure. The results are shown as the original concentrations in $\mathrm{pg} / \mathrm{mL}$ in the media without normalization. Data from two donors assessed in triplicate are shown $(n=6)$; *** $p<0.001 ;{ }^{* * * *} p<0.0001$.

\section{Discussion}

The present study sought to investigate the protective effect of the AGTR1 antagonist losartan on human NP cell inflammation and degeneration induced by TNF- $\alpha$. Outcomes revealed that TNF- $\alpha$ induced the expression of pathologic tRAS molecules and led to proinflammatory and catabolic effects in human NP cells. Inhibition of AGTR1 with losartan could partly inhibit the inflammatory and catabolic reaction. Therefore, present results suggest that TNF- $\alpha$-induced disc degeneration may partially be mediated through AGTR1 signaling. Treatment with AGTR1 antagonist losartan could inhibit the TNF- $\alpha$-induced degenerative state and maintain the NP cell phenotype depending on the administration or drug delivery method and the resulting achievable local tissue concentrations.

In accordance with previous studies, we found that losartan interacted with the PPAR $\gamma$ pathway [38]. Inhibition with the PPAR $\gamma$ inhibitor T0070907 partly abolished the effects of losartan on nucleus pulposus cells. This implies that the PPAR $\gamma$ pathway contributes to losartan's anti-inflammatory effects, as also suggested by Price et al. [20]. Our results also indicate that losartan has an impact on the gene expression of extracellular matrixrelated components. Losartan has been reported to affect TGF-beta expression and reduce collagen I production in human fibroblasts [39]. Additionally, the interaction of losartan with TGF-beta signaling was confirmed by other research groups [40].

Targeting the tissue renin-angiotensin system may have significant therapeutic potential in modulating the metabolism of the degenerative IVD, which may potentially translate into a reduction of discogenic pain.

\subsection{The Tissue Renin-Angiotensin System: AngII as a Pro-Inflammatory and Catabolic Hormone}

The renin-angiotensin system (RAS) has an important role in the regulation and progression of tissue injuries in the cardiovascular system [41]. In earlier studies, a variety 
of locally acting renin-angiotensin system components were identified in various human tissues, such as bone, gastrointestinal tract, skin, kidney, and liver, revealing an important role in degenerative and inflammatory processes [42,43]. AngII, a well-known classical vasoconstrictory cardiovascular hormone and part of the pathological arm of the tRAS, was also demonstrated to be produced in inflammatory cells, inducing nerve growth and axon sprouting [44-48]. For the first time, Morimoto et al. and Price et al. revealed the existence of local renin-angiotensin systems and their contribution to inflammation in the musculoskeletal system of rats $[20,49]$. Recent evidence underlines the statement that the RAS and its main effector, AngII, may be considered as a locally acting system, regulating tissue homeostasis and regeneration, especially in the cardiovascular and nervous systems [50]. Furthermore, AngII induces the expression of pro-inflammatory markers, such as IL-6, TNF- $\alpha$, and adhesion molecules, and functions as a true pro-inflammatory mediator that regulates inflammation, growth, and fibrosis [51-55].

In our previous work, we confirmed the existence of AngII and other tRAS components in tissue samples of degenerated discs by immunohistochemistry and gene expression analysis [16]. Disc tissue samples that expressed more tRAS factors showed significantly higher gene expression levels of pro-inflammatory (TNF- $\alpha$ IL-6) and catabolic genes (ADAMTS 4 and 5), indicating that tRAS contributes to the inflammatory processes operant in IDD. These findings are supported by the fact that the gene expression of NP phenotype-modulating factors, such as ACAN and COL2, was reduced in increased tRAS component-expressing discs. Furthermore, disc tissues with highly positive tRAS expression revealed lower glycosaminoglycan (GAG)/DNA ratios, implying the accelerated state of catabolism due to IDD.

Our present work indicates that AngII has the potential to affect IVD matrix degradation as the inhibition of its receptor, AGTR1, led to significant changes in the gene expression of relevant extracellular matrix genes. The roles of ACE and AGTR1 in inflammatory cell processes have previously been shown in synovium tissues from RA patients [20,56,57]. Recent research supports our work, revealing increased tRAS activity in the synovial fluid and tissues of patients with RA [58-60]. Price and coworkers analyzed the protective potential of losartan in rats with RA [20]. Chronic joint inflammation was induced by intraarticular and periarticular injection of Freund's complete adjuvant of heat-killed Mycobacterium tuberculosis into the knee joint. Acute joint inflammation was induced by intraarticular injection of $\lambda$-carrageenan and kaolin. Western blot analysis and immunohistochemistry reflected the elevated concentrations of AngII protein and AGTR1 in synovium from animals with acute and chronic joint inflammation. Losartan substantially reduced joint swelling and suppressed TNF- $\alpha$ generation in a dose-dependent manner. Morimoto et al. investigated the impact of AngII stimulation with different concentrations in rat annulus fibrosus cells by qRT-PCR [49]. Stimulation of rat IVD cells with AngII increased the mRNA expression of ADAMTS-5 significantly, indicating extracellular matrix degradation.

In summary, in accordance with other recent studies on musculoskeletal tissues, our current work provides strong evidence that the tRAS is involved in inflammatory and degenerative processes that are operant in IDD, and, therefore, introduces a novel therapeutic target to combat this devastating disease.

\subsection{Anti-Inflammatory Therapies Via RAS Inhibition-A Potential Target in IDD?}

Recent data consistently show that ARBs and ACE-inhibitors have anti-inflammatory effects in various human tissues and show beneficial effects in inflammatory musculoskeletal diseases [21-24,26-34,61]. Fukuzawa and coworkers demonstrated that oral administration of ACE inhibitors in mice reduced TNF- $\alpha$ release, though high concentrations were needed to reach a meaningful effect [18]. Further, RAS inhibitors abolished LPS-induced high IL-6 and TNF- $\alpha$ gene expression levels in the kidney [62]. Renal AngII is a key factor in mediating various components of the immune and inflammatory responses and acts as a pro-inflammatory agent $[55,63]$. This suggests that the administration of RAS inhibitor in 
therapeutic dosages to humans with hypertension may also suppress cytokine levels. The angiotensin-converting enzyme inhibitor Enalapril inhibits AngII synthesis from AngI and may suppress pro-inflammatory cytokine production, as previously shown in vitro $[64,65]$. Captopril, an ACE-inhibitor, is also known to have antirheumatic effects comparable to D-penicillamine [21,66,67]. Therefore, Captopril was considered a valuable drug in patients with hypertension and RA, especially due to the favorable benefit/risk ratio as Captopril lacks serious side effects [67]. Cardoso et al. demonstrated that losartan suppresses the expression of IL-6, IL-22, IL-17F, and IFN- $\gamma$ in Peripheral Blood Mononuclear Cells (PBMCs) from RA patients, suggesting that losartan could be a superior option for hypertension treatment in RA patients [68].

Our results reflect previous findings that found downregulations of inflammatory markers in inflammatory cell culture models after AGTR1 blockade or knockdown [69,70]. In contrast to our experiments, these studies used lipopolysaccharides to stimulate inflammation in the respective cell cultures and might not be fully comparable. However, our workgroup recently validated the superior potential of TNF- $\alpha$-induced inflammatory cell culture models to examine degenerative disc diseases [14]. Further, we showed for the first time that PPAR $\gamma$ pathway stimulation through losartan has protective effects on human NP cells. Losartan seems to exhibit at least some of its effect through the PPAR $\gamma$ pathway as the inhibition of PPAR $\gamma$ partly diminished the protective effects of losartan on the gene expression level. In accordance with the present results, several studies reported that losartan could get internalized through the AGTR1 receptor and act as a partial PPAR $\gamma$ agonist $[69,71,72]$. Noticeably, the PPAR $\gamma$ effects of ARBs might be too small regarding the reachable tissue levels to exert a significant anti-inflammatory effect. Therefore, new drug delivery methods and the development of new ARBs with more potent PPAR $\gamma$ activation properties or other PPAR $\gamma$ agonists might be needed if PPAR $\gamma$ stimulation is the target [73]. PPAR $\gamma$ activation properties of ARBs can be more seen as a beneficial effect in addition to the inhibition of the pathological tRAS arm (ACE/AngII/AGTR1 axis). Overall, more details about the interactions of the tRAS, PPAR $\gamma$ pathway, and ARBs in human IVD cells are warranted in the future.

Interestingly, the inhibition of AGTR1 receptors through losartan reduced TNF- $\alpha-$ induced ACE and AGTR1 upregulation. The upregulation of ACE through AGTR1 was already shown before by Koka et al. [74]. They also could inhibit this upregulation through losartan addition, which concurs with our data. Notably, as seen in our data, the inflammatory environments stimulate ACE and AGTR1 expression, indicating stimulation of the pathological arm of the tRAS in inflammatory settings. This was also shown by Takeshita et al., who suggested a previously unknown cross-talk between the TNF- $\alpha$ and the tRAS [75]. Therefore, the reproducible induction of the pathological arm of the tRAS by TNF- $\alpha$ for all examined donors in the present work suggests an important role in inflammatory and degenerative processes in IVDs. As shown by our data (Figure 3), losartan is especially effective in inflammatory settings, supporting its therapeutic potential in degenerative disc diseases.

\subsection{Strengths and Limitations}

The present study is associated with several strengths. The present experiments are the first pathway studies of the tRAS for IVD cells. As we used human NP cells from patients' IVDs in this study, these findings could directly impact clinical and therapeutic strategies in contrast to preclinical studies in other species that often need to be verified in humans first. We provided novel evidence that treatment with losartan suppresses pro-inflammatory and degenerative responses to inflammatory stimuli in human NP cells. We further revealed an interaction of the tRAS with the PPAR $\gamma$ pathway, which could be of potential interest for future pathway studies.

Some limitations need to be addressed to interpret the results adequately. Our studies were conducted in vitro using a 2-dimensional monolayer cell culture. In vivo interactions cannot be perfectly simulated with this methodological approach and the concentrations 
used for the intervention arms. The concentration range of losartan chosen in this experiment was based on previous in vitro pathway studies with other human cell types as evidence for intervertebral disc cells is scarce $[69,76,77]$. Therefore, the concentrations used in our cell cultures might not reflect the available tissue concentrations in humans after usual orally available doses of losartan. Reported oral doses of losartan range between 25 and $200 \mathrm{mg}$ per day. Its terminal half-life is approximately $2 \mathrm{~h}$, but its active metabolite EXP3174, which has a much more inhibitory effect on AGTR1 (up to 40-fold more potent), can reach a half-life of 6-9 h [78]. Reported maximal plasma concentrations in humans reached $84.5 \mathrm{ng} / \mathrm{mL}$ after a single oral administration of $25 \mathrm{mg}$ and $1394.9 \mathrm{ng} / \mathrm{mL}$ after single oral administration of $200 \mathrm{mg}$ losartan. For its active metabolite, these maximal plasma concentrations were $188.9 \mathrm{ng} / \mathrm{mL}$ and $2219.0 \mathrm{ng} / \mathrm{mL}$, respectively [79]. This would suggest that oral doses cannot accumulate the tissue concentrations needed for the anti-inflammatory effects seen in our results, at least in vitro. New drug delivery and administration techniques will be needed to reach these tissue concentrations. Another approach would be to find more potent inhibitors of the pathological tRAS arm or to evaluate stimulation of the protective tRAS arm components, which possibly will lead to anti-inflammatory effects in much lower concentrations. However, the present preclinical experiments help us understand the role of the tRAS and its inhibition in human NP cells, and support future planning of potential ex-vivo organ culture models followed by the in vivo studies needed in order to confirm these results. Furthermore, the range of TNF- $\alpha$ concentrations used to establish an inflammatory environment in NP cells was based on our workgroup's previous works [15] and does not reflect the tissue concentrations of TNF- $\alpha$ found in humans, which is reported to be around 5.9-25.9 pg/mL depending on the duration of complaints [80]. As this is a preclinical experiment in 2D NP cells, the inflammatory environment shown in our in vitro model cannot exactly simulate the inflammatory situation in vivo. Future degenerative disc in vivo models are needed here to translate these preclinical findings. Notably, we focused on changes in gene expression levels, and these changes might not reflect the changes in protein levels. Our ongoing studies involving different tRAS modulators, such as other AGTR1 inhibitors, will be conducted using expanded methodological techniques in order to visualize and quantify the tRAS components in NP cells and quantify protein concentrations of important inflammatory and tissue remodeling markers released by the cells. This expansion of methological techniques is highly warranted to examine the pathways leading to the current results. Whereas we found a protective anti-inflammatory effect of losartan based on downregulation of secreted IL-6 into the culture medium, we could not observe an inhibition of the protective losartan effects after PPAR $\gamma$ inhibition. Therefore, we cannot make a final conclusion regarding the PPAR $\gamma$ interactions with the tRAS on the protein level at this time. Our current results that indicate an involvement of the PPAR $\gamma$ pathway are based on the gene expression changes and need further validation in the future. Furthermore, we observed differences in the outcome effects sizes regarding the two timepoints, indicating that genes might be differently affected by tRAS modulation depending on exposure time. For example, tRAS gene expressions (ACE, AGT, CTSD, AGTR1) seem to be more affected by $24 \mathrm{~h}$ of losartan exposure than $72 \mathrm{~h}$. Future studies could include more time points and genes to ensure the identification of effects on relevant genes. Further, we did only observe significant effects on ACAN and collagen I gene expressions, but not collagen II gene expression, an important NP cell phenotype marker gene, indicating only partial effects on NP cell phenotype. Our ongoing experiments will include a broader examination of important genes and proteins that characterize the NP cell phenotype, in order to better evaluate the impact of tRAS modulation (including other tRAS modulators) on NP cell phenotype. Notably, we did not include other pivotal inflammatory markers such as prostaglandin E2, or cyclooxygenase-2. These markers need to be examined in the future, and this is already being planned by our workgroup, which will help clarify the interactions within NP cells. Moreover, other therapeutic approaches of tRAS modulation, such as the comparison of RAS inhibitors and stimulation of the protective tRAS arm, could be conducted 
and compared in order to evaluate the best therapeutic approach. Finally, an expansion of methodological techniques to quantify and visualize receptor expression changes is recommended and already planned by our group to characterize the nature of the tRAS in IVD degeneration.

\section{Conclusions}

TNF- $\alpha$ induced the expression of tRAS molecules and led to pro-inflammatory and catabolic effects in human NP cells. Inhibition of the angiotensin II receptor type 1 with losartan could inhibit this inflammatory and catabolic response. Further, we uncovered an interaction of losartan with the PPAR $\gamma$ pathway in human NP cells. These results demonstrate that TNF- $\alpha$-induced disc degeneration may be mediated partially through AGTR1 signaling. Treatment with AGTR1 antagonist losartan could inhibit the TNF- $\alpha-$ induced degeneration process and maintain the NP cell phenotype. The inhibition of the pathological tRAS pathway with angiotensin II receptor type 1 blockers could be a novel therapeutic strategy for discogenic back pain caused by intervertebral disc degeneration.

Author Contributions: Conceptualization: Z.L., S.G., M.A., R.G.R., H.S., and G.L.; Data curation: B.S., Z.L., J.P., and L.W.; Formal analysis: B.S., Z.L., J.P., and L.W.; Investigation: S.G., M.A., C.L., N.S., H.S., and G.L.; Methodology: Z.L., J.P., C.E.A., S.H., S.G., and G.L.; Project administration: Z.L., S.G., M.A., R.G.R., N.S., H.S., and G.L.; Supervision: C.E.A., M.A., R.G.R., N.S., and G.L.; Validation: R.G.R. and C.L.; Visualization: B.S.; Writing-original draft: B.S. and G.L.; Writing-review \& editing: B.S., Z.L., J.P., L.W., C.E.A., S.H., S.G., M.A., R.G.R., C.L., N.S., H.S., and G.L. All authors have read and agreed to the published version of the manuscript.

Funding: This study was funded by the German Spine Society (DWG), German Arthritis Foundation (DAH), the Foundation for the Promotion of Alternate and Complementary Methods to Reduce Animal Testing (SET) under the project InflamoDisc [number 59], AO Foundation, and AOSpine International. GL was supported by the Berta-Ottenstein Programme for Advanced Clinician Scientists, Faculty of Medicine, University of Freiburg.

Institutional Review Board Statement: Ethical approval was not necessary for this study. The Swiss Human Research Act does not apply to research that utilizes anonymized biological material and/or anonymously collected or anonymized health-related data. Therefore, this project does not need to be approved by an ethics committee.

Informed Consent Statement: Patients' informed consent was obtained from all subjects involved in the study.

Data Availability Statement: Datasets are available on request. The raw data and all related documents supporting the conclusions of this manuscript will be made available by the authors, without undue reservation, to any qualified researcher.

Acknowledgments: The article processing charge was funded by the Baden-Wuerttemberg Ministry of Science, Research and Art, and the University of Freiburg in the funding program Open Access Publishing.

Conflicts of Interest: The authors declare no conflict of interest.

\section{References}

1. Vos, T.; Abajobir, A.A.; Abate, K.H.; Abbafati, C.; Abbas, K.M.; Abd-Allah, F.; Abdulkader, R.S.; Abdulle, A.M.; Abebo, T.A.; Abera, S.F.; et al. Global, regional, and national incidence, prevalence, and years lived with disability for 328 diseases and injuries for 195 countries, 1990-2016: A systematic analysis for the Global Burden of Disease Study 2016. Lancet 2017, 390, 1211-1259. [CrossRef]

2. Battié, M.C.; Joshi, A.B.; Gibbons, L.E. Degenerative Disc Disease: What is in a Name? Spine 2019, 44, 1523-1529. [CrossRef] [PubMed]

3. Adams, M.A.; Roughley, P.J. What is Intervertebral Disc Degeneration, and What Causes It? Spine 2006, 31, 2151-2161. [CrossRef]

4. Risbud, M.V.; Shapiro, I.M. Role of cytokines in intervertebral disc degeneration: Pain and disc content. Nat. Rev. Rheumatol. 2014, 10, 44-56. [CrossRef] [PubMed]

5. Takahashi, H.; Suguro, T.; Okazima, Y.; Motegi, M.; Okada, Y.; Kakiuchi, T. Inflammatory Cytokines in the Herniated Disc of the Lumbar Spine. Spine 1996, 21, 218-224. [CrossRef] 
6. Mannion, A.F.; Impellizzeri, F.M.; Leunig, M.; Jeszenszy, D.; Becker, H.-J.; Haschtmann, D.; Preiss, S.; Fekete, T.F. Eurospine 2017 full paper award: Time to remove our rose-tinted spectacles: A candid appraisal of the relative success of surgery in over 4500 patients with degenerative disorders of the lumbar spine, hip or knee. Eur. Spine J. 2018, 27, 778-788. [CrossRef]

7. Wahood, W.; Yolcu, Y.U.; Kerezoudis, P.; Goyal, A.; Alvi, M.A.; Freedman, B.A.; Bydon, M. Artificial Discs in Cervical Disc Replacement: A Meta-Analysis for Comparison of Long-Term Outcomes. World Neurosurg. 2020, 134, 598-613.e5. [CrossRef]

8. Gangl, M. Spezifischer Kreuzschmerz-Die erste Leitlinie. Man. Med. 2020, 58, 46-52. [CrossRef]

9. Findlay, C.; Ayis, S.; Demetriades, A.K. Total disc replacement versus anterior cervical discectomy and fusion: A systematic review with meta-analysis of data from a total of 3160 patients across 14 randomized controlled trials with both short- and medium- to long-term outcomes. Bone Jt. J. 2018, 100-B, 991-1001. [CrossRef] [PubMed]

10. Petersen, T.; Laslett, M.; Juhl, C. Clinical classification in low back pain: Best-evidence diagnostic rules based on systematic reviews. BMC Musculoskelet Disord. 2017, 18, 188. [CrossRef] [PubMed]

11. Rustenburg, C.M.E.; Faraj, S.S.A.; Ket, J.C.F.; Emanuel, K.S.; Smit, T.H. Prognostic factors in the progression of intervertebral disc degeneration: Which patient should be targeted with regenerative therapies? JOR Spine 2019, 2. [CrossRef] [PubMed]

12. Smith, L.J.; Silverman, L.; Sakai, D.; Le Maitre, C.L.; Mauck, R.L.; Malhotra, N.R.; Lotz, J.C.; Buckley, C.T. Advancing cell therapies for intervertebral disc regeneration from the lab to the clinic: Recommendations of the ORS spine section. JOR Spine 2018, 1, e1036. [CrossRef] [PubMed]

13. Buckley, C.T.; Hoyland, J.A.; Fujii, K.; Pandit, A.; Iatridis, J.C.; Grad, S. Critical aspects and challenges for intervertebral disc repair and regeneration-Harnessing advances in tissue engineering. JOR Spine 2018, 1, e1029. [CrossRef] [PubMed]

14. Li, Z.; Gehlen, Y.; Heizmann, F.; Grad, S.; Alini, M.; Richards, R.G.; Kubosch, D.; Südkamp, N.; Izadpanah, K.; Kubosch, E.J.; et al. Preclinical ex-vivo Testing of Anti-inflammatory Drugs in a Bovine Intervertebral Degenerative Disc Model. Front. Bioeng. Biotechnol. 2020, 8, 583. [CrossRef]

15. Du, J.; Pfannkuche, J.; Lang, G.; Häckel, S.; Creemers, L.B.; Alini, M.; Grad, S.; Li, Z. Proinflammatory intervertebral disc cell and organ culture models induced by tumor necrosis factor alpha. JOR Spine 2020. [CrossRef]

16. Li, Z.; Wystrach, L.; Bernstein, A.; Grad, S.; Alini, M.; Richards, R.; Kubosch, D.; Südkamp, N.; Izadpanah, K.; Kubosch, E.; et al. The tissue-renin-angiotensin-system of the human intervertebral disc. eCM 2020, 40, 115-132. [CrossRef]

17. Stagnitti, M.N. Trends in Utilization and Expenditures of Prescribed Drugs Treating Diabetes, Hypertension, and High Cholesterol for Persons under Age 40 in the U.S. Civilian Noninstitutionalized Population, 2000 and 2010. In Statistical Brief (Medical Expenditure Panel Survey (US)); Agency for Healthcare Research and Quality (US): Rockville, MD, USA, 2001.

18. Fukuzawa, M.; Satoh, J.; Sagara, M.; Muto, G.; Muto, Y.; Nishimura, S.; Miyaguchi, S.; Qiang, X.L.; Sakata, Y.; Nakazawa, T.; et al. Angiotensin converting enzyme inhibitors suppress production of tumor necrosis factor- $\alpha$ in vitro and in vivo. Immunopharmacology 1997, 36, 49-55. [CrossRef]

19. Saravi, B.; Lang, G.; Ülkümen, S.; Burchard, T.; Weihrauch, V.; Patzelt, S.; Boeker, M.; Li, Z.; Woelber, J.P. The tissue reninangiotensin system (tRAS) and the impact of its inhibition on inflammation and bone loss in the periodontal tissue. Eur. Cell Mater. 2020, 40, 203-226. [CrossRef]

20. Price, A.; Lockhart, J.C.; Ferrell, W.R.; Gsell, W.; McLean, S.; Sturrock, R.D. Angiotensin II type 1 receptor as a novel therapeutic target in rheumatoid arthritis: In vivo analyses in rodent models of arthritis and ex vivo analyses in human inflammatory synovitis. Arthritis Rheum. 2007, 56, 441-447. [CrossRef]

21. Agha, A.M.; Mansour, M. Effects of Captopril on Interleukin-6, Leukotriene B4, and Oxidative Stress Markers in Serum and Inflammatory Exudate of Arthritic Rats: Evidence of Antiinflammatory Activity. Toxicol. Appl. Pharmacol. 2000, 168, 123-130. [CrossRef]

22. Dalbeth, N. The non-thiol angiotensin-converting enzyme inhibitor quinapril suppresses inflammatory arthritis. Rheumatology 2005, 44, 24-31. [CrossRef] [PubMed]

23. Flammer, A.J.; Sudano, I.; Hermann, F.; Gay, S.; Forster, A.; Neidhart, M.; Künzler, P.; Enseleit, F.; Périat, D.; Hermann, M.; et al. Angiotensin-Converting Enzyme Inhibition Improves Vascular Function in Rheumatoid Arthritis. Circulation 2008, 117, $2262-2269$. [CrossRef] [PubMed]

24. Liu, H.-M.; Wang, K.-J. Therapeutic effect of Captopril on rheumatoid arthritis in rats. Asian Pac. J. Trop. Med. 2014, 7, 996-999. [CrossRef]

25. Miyagi, M.; Ishikawa, T.; Kamoda, H.; Suzuki, M.; Murakami, K.; Shibayama, M.; Orita, S.; Eguchi, Y.; Arai, G.; Sakuma, Y.; et al. ISSLS Prize Winner: Disc Dynamic Compression in Rats Produces Long-Lasting Increases in Inflammatory Mediators in Discs and Induces Long-Lasting Nerve Injury and Regeneration of the Afferent Fibers Innervating Discs. Spine 2012, 37, $1810-1818$. [CrossRef] [PubMed]

26. Tang, Y.; Hu, X.; Lu, X. Captopril, an angiotensin-converting enzyme inhibitor, possesses chondroprotective efficacy in a rat model of osteoarthritis through suppression local renin-angiotensin system. Int. J. Clin. Exp. Med. 2015, 8, 12584-12592.

27. Fahmy Wahba, M.G.; Shehata Messiha, B.A.; Abo-Saif, A.A. Ramipril and haloperidol as promising approaches in managing rheumatoid arthritis in rats. Eur. J. Pharmacol. 2015, 765, 307-315. [CrossRef]

28. Guerra, G.C.B.; de Menezes, M.S.S.; de Araújo, A.A.; de Araújo Júnior, R.F.; de Medeiros, C.A.C.X. Olmesartan Prevented Intra-articular Inflammation Induced by Zymosan in Rats. Biol. Pharm. Bull. 2016, 39, 1793-1801. [CrossRef]

29. Sagawa, K.; Nagatani, K.; Komagata, Y.; Yamamoto, K. Angiotensin receptor blockers suppress antigen-specific T cell responses and ameliorate collagen-induced arthritis in mice. Arthritis Rheum. 2005, 52, 1920-1928. [CrossRef] 
30. Refaat, R.; Salama, M.; Abdel Meguid, E.; El Sarha, A.; Gowayed, M. Evaluation of the effect of losartan and methotrexate combined therapy in adjuvant-induced arthritis in rats. Eur. J. Pharmacol. 2013, 698, 421-428. [CrossRef]

31. Silveira, K.D.; Coelho, F.M.; Vieira, A.T.; Barroso, L.C.; Queiroz-Junior, C.M.; Costa, V.V.; Sousa, L.F.C.; Oliveira, M.L.; Bader, M.; Silva, T.A.; et al. Mechanisms of the anti-inflammatory actions of the angiotensin type 1 receptor antagonist losartan in experimental models of arthritis. Peptides 2013, 46, 53-63. [CrossRef]

32. Wang, D.; Hu, S.; Zhu, J.; Yuan, J.; Wu, J.; Zhou, A.; Wu, Y.; Zhao, W.; Huang, Q.; Chang, Y.; et al. Angiotensin II type 2 receptor correlates with therapeutic effects of losartan in rats with adjuvant-induced arthritis. J. Cell. Mol. Med. 2013, 17, 1577-1587. [CrossRef] [PubMed]

33. Queiroz-Junior, C.M.; Silveira, K.D.; de Oliveira, C.R.; Moura, A.P.; Madeira, M.F.M.; Soriani, F.M.; Ferreira, A.J.; Fukada, S.Y.; Teixeira, M.M.; Souza, D.G.; et al. Protective effects of the angiotensin type 1 receptor antagonist losartan in infection-induced and arthritis-associated alveolar bone loss. J. Periodontal. Res. 2015, 50, 814-823. [CrossRef] [PubMed]

34. Perry, M.E.; Chee, M.M.; Ferrell, W.R.; Lockhart, J.C.; Sturrock, R.D. Angiotensin receptor blockers reduce erythrocyte sedimentation rate levels in patients with rheumatoid arthritis. Ann. Rheum. Dis. 2008, 67, 1646-1647. [CrossRef] [PubMed]

35. Ruiz-Ortega, M.; Lorenzo, O.; Suzuki, Y.; Rupérez, M.; Egido, J. Proinflammatory actions of angiotensins. Curr. Opin. Nephrol. Hypertens. 2001, 10, 321-329. [CrossRef]

36. Wolf, G.; Neilson, E.G. Angiotensin II as a renal growth factor. J. Am. Soc. Nephrol. 1993, 3, 1531-1540.

37. Mezzano, S.A.; Ruiz-Ortega, M.; Egido, J. Angiotensin II and Renal Fibrosis. Hypertension 2001, 38, 635-638. [CrossRef]

38. Schupp, M.; Janke, J.; Clasen, R.; Unger, T.; Kintscher, U. Angiotensin Type 1 Receptor Blockers Induce Peroxisome ProliferatorActivated Receptor- $\gamma$ Activity. Circulation 2004, 109, 2054-2057. [CrossRef]

39. Diop-Frimpong, B.; Chauhan, V.P.; Krane, S.; Boucher, Y.; Jain, R.K. Losartan inhibits collagen I synthesis and improves the distribution and efficacy of nanotherapeutics in tumors. Proc. Natl. Acad. Sci. USA 2011, 108, 2909-2914. [CrossRef]

40. Cohn, R.D.; van Erp, C.; Habashi, J.P.; Soleimani, A.A.; Klein, E.C.; Lisi, M.T.; Gamradt, M.; ap Rhys, C.M.; Holm, T.M.; Loeys, B.L.; et al. Angiotensin II type 1 receptor blockade attenuates TGF- $\beta$-induced failure of muscle regeneration in multiple myopathic states. Nat. Med. 2007, 13, 204-210. [CrossRef]

41. Namsolleck, P.; Recarti, C.; Foulquier, S.; Steckelings, U.M.; Unger, T. AT2 Receptor and Tissue Injury: Therapeutic Implications. Curr. Hypertens. Rep. 2014, 16, 416. [CrossRef]

42. Patil, J.; Schwab, A.; Nussberger, J.; Schaffner, T.; Saavedra, J.M.; Imboden, H. Intraneuronal angiotensinergic system in rat and human dorsal root ganglia. Regul. Pept. 2010, 162, 90-98. [CrossRef] [PubMed]

43. Paul, M.; Poyan Mehr, A.; Kreutz, R. Physiology of Local Renin-Angiotensin Systems. Physiol. Rev. 2006, 86, 747-803. [CrossRef] [PubMed]

44. Hoch, N.E.; Guzik, T.J.; Chen, W.; Deans, T.; Maalouf, S.A.; Gratze, P.; Weyand, C.; Harrison, D.G. Regulation of T-cell function by endogenously produced angiotensin II. Am. J. Physiol. Regul. Integr. Comp. Physiol. 2009, 296, R208-R216. [CrossRef] [PubMed]

45. Jurewicz, M.; McDermott, D.H.; Sechler, J.M.; Tinckam, K.; Takakura, A.; Carpenter, C.B.; Milford, E.; Abdi, R. Human T and Natural Killer Cells Possess a Functional Renin-Angiotensin System: Further Mechanisms of Angiotensin II-Induced Inflammation. JASN 2007, 18, 1093-1102. [CrossRef] [PubMed]

46. Chakrabarty, A.; Blacklock, A.; Svojanovsky, S.; Smith, P.G. Estrogen Elicits Dorsal Root Ganglion Axon Sprouting via a Renin-Angiotensin System. Endocrinology 2008, 149, 3452-3460. [CrossRef]

47. Côté, F.; Do, T.H.; Laflamme, L.; Gallo, J.-M.; Gallo-Payet, N. Activation of the $\mathrm{AT}_{2}$ Receptor of Angiotensin II Induces Neurite Outgrowth and Cell Migration in Microexplant Cultures of the Cerebellum. J. Biol. Chem. 1999, 274, 31686-31692. [CrossRef]

48. Gendron, L.; Côté, F.; Payet, M.D.; Gallo-Payet, N. Nitric Oxide and Cyclic GMP Are Involved in Angiotensin II AT 2 Receptor Effects on Neurite Outgrowth in NG108-15 Cells. Neuroendocrinology 2002, 75, 70-81. [CrossRef]

49. Morimoto, R.; Akeda, K.; Iida, R.; Nishimura, A.; Tsujii, M.; Obata, S.; Kasai, Y.; Uchida, A.; Sudo, A. Tissue renin-angiotensin system in the intervertebral disc. Spine 2013, 38, E129-E136. [CrossRef]

50. Unger, T.; Steckelings, U.M.; dos Santos, R.S. The Protective Arm of the Renin Angiotensin: Functional Aspects and Therapeutic Implications; Academic Press: Cambridge, MA, USA, 2015; ISBN 978-0-12-801485-1.

51. Han, Y.; Runge, M.S.; Brasier, A.R. Angiotensin II Induces Interleukin-6 Transcription in Vascular Smooth Muscle Cells Through Pleiotropic Activation of Nuclear Factor-kB Transcription Factors. Circ. Res. 1999, 84, 695-703. [CrossRef]

52. Moriyama, T.; Fujibayashi, M.; Fujiwara, Y.; Kaneko, T.; Xia, C.; Imai, E.; Kamada, T.; Ando, A.; Ueda, N. Angiotensin II stimulates interleukin-6 release from cultured mouse mesangial cells. J. Am. Soc. Nephrol. 1995, 6, 95-101.

53. Ruiz-Ortega, M.; Ruperez, M.; Lorenzo, O.; Esteban, V.; Blanco, J.; Mezzano, S.; Egido, J. Angiotensin II regulates the synthesis of proinflammatory cytokines and chemokines in the kidney. Kidney Int. 2002, 62, S12-S22. [CrossRef] [PubMed]

54. Ekholm, M.; Kahan, T.; Jörneskog, G.; Bröijersen, A.; Wallén, N.H. Angiotensin II infusion in man is proinflammatory but has no short-term effects on thrombin generation in vivo. Thromb. Res. 2009, 124, 110-115. [CrossRef] [PubMed]

55. Ekholm, M.; Kahan, T.; Jörneskog, G.; Brinck, J.; Wallén, N.H. Haemostatic and inflammatory alterations in familial hypercholesterolaemia, and the impact of angiotensin II infusion. J. Renin. Angiotensin. Aldosterone Syst. 2015, 16, 328-338. [CrossRef] [PubMed]

56. Walsh, D.A.; Mapp, P.I.; Wharton, J.; Polak, J.M.; Blake, D.R. Neuropeptide degrading enzymes in normal and inflamed human synovium. Am. J. Pathol. 1993, 142, 1610-1621. [PubMed] 
57. Walsh, D.A. Angiotensin converting enzyme in human synovium: Increased stromal [125I]351A binding in rheumatoid arthritis. Ann. Rheum. Dis. 2000, 59, 125-131. [CrossRef]

58. Goto, M.; Fujisawa, M.; Yamada, A.; Okabe, T.; Takaku, F.; Sasano, M.; Nishioka, K. Spontaneous release of angiotensin converting enzyme and interleukin 1 beta from peripheral blood monocytes from patients with rheumatoid arthritis under a serum free condition. Ann. Rheum. Dis. 1990, 49, 172-176. [CrossRef]

59. Goto, M.; Sasano, M.; Fuzisawa, M.; Okabe, T.; Nishizawa, K. Constitutive production of angiotensin converting enzyme from rheumatoid nodule cells under serum free conditions. Ann. Rheum. Dis. 1992, 51, 741-742. [CrossRef] [PubMed]

60. Veale, D.; Yanni, G.; Bresnihan, B.; FitzGerald, O. Production of angiotensin converting enzyme by rheumatoid synovial membrane. Ann. Rheum. Dis. 1992, 51, 476-480. [CrossRef] [PubMed]

61. Shi, Q.; Abusarah, J.; Baroudi, G.; Fernandes, J.C.; Fahmi, H.; Benderdour, M. Ramipril attenuates lipid peroxidation and cardiac fibrosis in an experimental model of rheumatoid arthritis. Arthritis Res. 2012, 14, R223. [CrossRef] [PubMed]

62. Niimi, R.; Nakamura, A.; Yanagawa, Y. Suppression of Endotoxin-Induced Renal Tumor Necrosis Factor- $\alpha$ and Interleukin-6 mRNA by Renin-Angiotensin System Inhibitors. Jpn. J. Pharm. 2002, 88, 139-145. [CrossRef] [PubMed]

63. Rüster, C.; Wolf, G. Angiotensin II as a Morphogenic Cytokine Stimulating Renal Fibrogenesis. JASN 2011, 22, 1189-1199. [CrossRef]

64. Schindler, R.; Dinarello, C.A.; Koch, K.-M. Angiotensin-converting-enzyme inhibitors suppress synthesis of tumour necrosis factor and interleukin 1 by human peripheral blood mononuclear cells. Cytokine 1995, 7, 526-533. [CrossRef]

65. Peeters, A.C.T.M.; Netea, M.G.; Kullberg, B.J.; Thien, T.; Van Der Meer, J.W.M. The effect of renin-angiotensin system inhibitors on pro- and anti-inflammatory cytokine production. Immunology 1998, 94, 376-379. [CrossRef]

66. Popa, C.D.; van Riel, P.L.C.M. The Use of Captopril in Rheumatoid Arthritis: Combining Treatment Targets! Can. J. Cardiol. 2013, 29, 639.e13. [CrossRef] [PubMed]

67. Martin, M.F.R.; Mckenna, F.; Bird, H.A.; Surrall, K.E.; Dixon, J.S.; Wright, V. CAPTOPRIL: A NEW TREATMENT FOR RHEUMATOID ARTHRITIS? Lancet 1984, 323, 1325-1328. [CrossRef]

68. Cardoso, P.R.G.; Matias, K.A.; Dantas, A.T.; Marques, C.D.L.; Pereira, M.C.; Duarte, A.L.B.P.; de Melo Rego, M.J.B.; da Rocha Pitta, I.; da Rocha Pitta, M.G. Losartan, but not Enalapril and Valsartan, Inhibits the Expression of IFN- $\gamma$, IL-6, IL-17F and IL-22 in PBMCs from Rheumatoid Arthritis Patients. TORJ 2018, 12, 160-170. [CrossRef] [PubMed]

69. An, J.; Nakajima, T.; Kuba, K.; Kimura, A. Losartan inhibits LPS-induced inflammatory signaling through a PPAR $\gamma$-dependent mechanism in human THP-1 macrophages. Hypertens. Res. 2010, 33, 831-835. [CrossRef]

70. Wong, M.H.; Chapin, O.C.; Johnson, M.D. LPS-Stimulated Cytokine Production in Type I Cells Is Modulated by the ReninAngiotensin System. Am. J. Respir. Cell Mol. Biol. 2012, 46, 641-650. [CrossRef]

71. Schupp, M.; Lee, L.D.; Frost, N.; Umbreen, S.; Schmidt, B.; Unger, T.; Kintscher, U. Regulation of Peroxisome Proliferator-Activated Receptor $\gamma$ Activity by Losartan Metabolites. Hypertension 2006, 47, 586-589. [CrossRef]

72. Villar-Cheda, B.; Costa-Besada, M.A.; Valenzuela, R.; Perez-Costas, E.; Melendez-Ferro, M.; Labandeira-Garcia, J.L. The intracellular angiotensin system buffers deleterious effects of the extracellular paracrine system. Cell Death Dis. 2017, 8, e3044. [CrossRef]

73. Fujimura, A.; Ushijima, K.; Ando, H. Does the PPAR- $\gamma$-activating property of telmisartan provide a benefit in clinical practice? Hypertens Res. 2013, 36, 183. [CrossRef] [PubMed]

74. Koka, V.; Huang, X.R.; Chung, A.C.K.; Wang, W.; Truong, L.D.; Lan, H.Y. Angiotensin II Up-Regulates Angiotensin I-Converting Enzyme (ACE), but Down-Regulates ACE2 via the AT1-ERK/p38 MAP Kinase Pathway. Am. J. Pathol. 2008, 172, 1174-1183. [CrossRef] [PubMed]

75. Takeshita, Y.; Takamura, T.; Ando, H.; Hamaguchi, E.; Takazakura, A.; Matsuzawa-Nagata, N.; Kaneko, S. Cross talk of tumor necrosis factor- $\alpha$ and the renin-angiotensin system in tumor necrosis factor- $\alpha$-induced plasminogen activator inhibitor- 1 production from hepatocytes. Eur. J. Pharmacol. 2008, 579, 426-432. [CrossRef] [PubMed]

76. Soldner, A.; Benet, L.Z.; Mutschler, E.; Christians, U. Active transport of the angiotensin-II antagonist losartan and its main metabolite EXP 3174 across MDCK-MDR1 and Caco-2 cell monolayers: Active transport of losartan and EXP 3174. Br. J. Pharmacol. 2000, 129, 1235-1243. [CrossRef]

77. Chang, L.-T.; Sun, C.-K.; Chiang, C.-H.; Wu, C.-J.; Chua, S.; Yip, H.-K. Impact of simvastatin and losartan on antiinflammatory effect: In vitro study. J. Cardiovasc. Pharm. 2007, 49, 20-26. [CrossRef]

78. Sica, D.A.; Gehr, T.W.B.; Ghosh, S. Clinical pharmacokinetics of losartan. Clin. Pharm. 2005, 44, 797-814. [CrossRef]

79. Ohtawa, M.; Takayama, F.; Saitoh, K.; Yoshinaga, T.; Nakashima, M. Pharmacokinetics and biochemical efficacy after single and multiple oral administration of losartan, an orally active nonpeptide angiotensin II receptor antagonist, in humans. Br. J. Clin. Pharm. 1993, 35, 290-297. [CrossRef]

80. Altun, I. Cytokine profile in degenerated painful intervertebral disc: Variability with respect to duration of symptoms and type of disease. Spine J. 2016, 16, 857-861. [CrossRef] 